\title{
On the role of contestations, the power of reflexive authority, and legitimation problems in the global political system
}

\author{
Michael Zürn \\ WZB Berlin Social Science Center, Berlin, Germany \\ Corresponding author. E-mail: zuern@wzb.eu
}

(Received 9 June 2020; accepted 26 June 2020; first published online 28 December 2020)

\begin{abstract}
This response to my critics discusses four claims that are central for A Theory of Global Governance. The first claim is that observing a high level of conflict and contestation in world politics is not proof of the unimportance of global governance, since many of the current conflicts and contestations are about international institutions. The second claim is that the 1990s saw a rise of trans- and international authority beyond the nation-state that is essential for the rise of a global political system. Third, a global system of loosely coupled spheres of authority relies on 'critical deference' (reflexive authority) but also contains numerous elements of coercion. And fourth, a technocratic legitimation of intrusive international authorities cannot build on emotions or a sense of belonging. This deficit creates a political opportunity structure that allows for the rise of a myriad of dissenters. The relative importance of them depends on the availability of resources for mobilization and not on the quality of reasons for resistance.
\end{abstract}

Keywords: global governance; nationalism; coercion; dissent; theory

Imagine you have a choice: either you write a book, and no one mentions it, or you write a book, and everyone criticizes it. I prefer the latter. It is indeed a privilege to read the critical comments by a group of distinguished scholars representing different orientations and covering almost all theoretical camps in International Relations (IR). I enjoyed not only the praise, but especially the critical reflections. They all are insightful, challenging, constructive, and they help carry on the theoretical debate. These criticisms are drawn together in a sophisticated introduction that captures the arguments of $A$ Theory of Global Governance in incredibly pertinent and elegant ways. ${ }^{1}$ Similarly, Keohane provides a crystal clear and succinct summary of the arguments in A Theory. ${ }^{2}$ This response therefore focuses on four questions raised by symposium contributors: Is the concept of global governance

\footnotetext{
${ }^{1}$ Fioretos and Tallberg 2020.

${ }^{2}$ Keohane 2020.

(C) The Author(s), 2020. Published by Cambridge University Press. This is an Open Access article, distributed under the terms of the Creative Commons Attribution licence (http://creativecommons.org/licenses/by/4.0/), which permits unrestricted re-use, distribution, and reproduction in any medium, provided the original work is properly cited.
} 
still useful given the contemporary rise of nationalism and geopolitics? When did global governance start? To what extent does global governance involve elements of coercion and domination? And what are the targets of dissenters of global governance?

\section{The current crisis of global governance}

The year 2016 was a bad year for global governance. It demonstrated, above all, the strength of nationalist sentiments and forces within Western democracies. Parties with an anti-internationalist orientation gained strength almost everywhere. Additionally, the British people voted for Brexit, hitting the European integration project hard, and the American people elected Donald Trump as president of the United States of America. All of these forces are united by a preference for closing borders for people and increasingly also industrial goods, a rejection of any political authority beyond the nation-state, and strong arguments in favor of national sovereignty. Moreover, authoritarian populists within Western democracies seem to coalesce with authoritarian potentates in power, such as Putin, Erdoğan, Modi, and Orbán - all of them elected - in a network of enemies of global governance. These developments represent a fundamental challenge to global governance. As Kelley and Simmons put it succinctly: 'Global governance has never seemed more necessary, and yet so under attack'.

As if Trump had read A Theory of Global Governance, he precisely questions the three central normative foundations of the global political system spelled out in that book. In the preface to the National Security Strategy (NSS), published around the same time, he rejects first of all the very idea of global common goods: 'My administration's National Security Strategy lays out a strategic vision for protecting the American people and preserving our way of life, promoting our prosperity, preserving peace through strength, and advancing American influence in the world'. Common interests, public goods, or global common goods receive no mention, and peace is equated with American dominance. Second, Trump denounces international institutions as unnecessary in principle. The withdrawals of the United States from the Trans-Pacific Partnership and the Paris Climate Agreement are therefore framed as 'successes' of his policies. Finally, neither the President's preface nor the NSS as a whole do at any point give the impression that the United States is concerned with people, groups, or governments outside the country. A justification of the strategy toward all those affected by it does not take place.

Against this background, Keohane asks whether the global politics paradigm advanced in A Theory can help us understand world politics of today, or whether recent political developments fall outside its scope conditions. ${ }^{4}$ No question, the last few years have seen strong resistance to and more signs of decline than deepening of global governance. Yet, I want to maintain that observing a high level of conflict and contestation in world politics is not proof of the unimportance of global governance. It may in fact suggest the opposite. Authoritative international institutions are seen by many as detrimental to identity concerns and national interests,

\footnotetext{
${ }^{3}$ Kelley and Simmons 2020, 169.

${ }^{4}$ Keohane 2020.
} 
and therefore current conflicts and contestations take place in and often about international institutions. Therefore, the analytical disassociation between international institutions and cooperation is necessary and long overdue, as Pouliot points out. ${ }^{5}$ A Theory even offers an explanation for why the international institutions of the 1990s are under fire by very different actors simultaneously. By pointing to the dominance of liberal cosmopolitans from a few (especially) Western powers in these institutions and their technocratic mode of decision making, $A$ Theory develops an endogenous explanation for the epidemic rise of challenges. Challenges to global governance can be reformist (questioning the legitimate exercise of authority), or revisionist (questioning the authority as such); they can be caused by either identity concerns or material interests; and they may lead to the revival of geopolitics or a change in the mode of global governance.

The explanation may be wrong or partial, but it cannot be rejected by simply pointing to revisionist dissenters, a declining importance of institutions, or shrinking spaces of consensus. Observing a rise in the level of conflict and contestation in IR, even if revisionist and fundamental, is not a proof of the unimportance of international institutions. Nationalist forces today do not - as was the case in the $19^{\text {th }}$ and early $20^{\text {th }}$ centuries - aim at other nations and people but, above all, direct their ire at international institutions. China and other rising powers do not openly challenge the American or European spheres of influence, but they want to adapt international institutions to their needs. And anti-neo-liberal forces do not want to get rid of international institutions, but aim at changing them. The commonality of all of the challenges to global governance is that they consider international institutions to be too powerful. All of these contestations take place in a transnational struggle that cuts across levels of analysis in which statist defenders of national sovereignty are pitted against liberal cosmopolitans who emphasize human rights, international institutions, and open borders. ${ }^{6}$ Although it is certainly correct that the empirical chapters in $A$ Theory focus more on reformist contestations, the ambition of the theory is to account for revisionist forces as well.

For instance, an endogenous explanation of the current crisis of global governance arguably is relevant for explaining the rise of authoritarian populists who challenge international institutions. In addition to the well-known economic and cultural accounts, ${ }^{7}$ it points to the historical compromise of embedded liberalism ${ }^{8}$ that has triggered a dynamic in which the rise of so-called non-majoritarian institutions (NMIs) such as central banks, constitutional courts, and international organizations (IOs) has locked in certain policies. As a consequence, especially people with little education and transnational capacities feel excluded from the political process. They consider themselves as suppressed, or at least forgotten, by liberal cosmopolitan experts supposedly controlling NMIs at the expense of majoritarian institutions such as parties and parliaments that are the sources of influence for the majority. It is for these reasons that authoritarian populists pit the notion of the will

\footnotetext{
${ }^{5}$ Pouliot 2020.

${ }^{6}$ de Wilde et al. 2019, forthcoming.

${ }^{7}$ See, e.g. Inglehart and Norris 2016.

${ }^{8}$ Ruggie 1983.
} 
of the people against NMIs as a major fault line in contemporary politics. ${ }^{9}$ The legitimation deficits of the existing global governance system have thus contributed significantly to the rise of authoritarian populists, who do not question only the legitimate exercise of authority by international institutions but also the need for any authority beyond the nation-state at all.

This challenge to international and transnational authority indeed pushes global governance into crisis. However, external revisionist contestation has thus far not succeeded in overturning the existing order completely. An authority crisis in a global political system is something else than anarchy in the international system. For the time being, it seems more likely that the challenges to the global governance system - describing the current form of a global political system - may lead to changes in its mode of working rather than its total demise. The dichotomy between decline and deepening, therefore, is in fact overly simple, as Barnett notes. ${ }^{10}$ Morse and Keohane, for instance, have shown that actors who are dissatisfied with international institutions rarely chose exit but aim for the establishment of counter-institutions. ${ }^{11}$

In the end, it may be that the current wave of challenges to global governance leads to its decline and possibly even to a revival of geopolitics. In this case, $A$ Theory would indeed lose relevance to understand the future of world politics. Yet, it would remain relevant in explaining why we moved away from the post-World War II order and back to the world of geopolitics.

\section{The timing of global governance}

Another set of comments speaks to the origins of global governance. Barnett and Scholte suggest that we may go back further in time to find the sources of contemporary global governance in long-standing diplomatic practices and capitalism. ${ }^{12}$ Although there is no question that the current global governance system has longstanding roots, I argue that it is only after the 1990s that a global political system emerged. A whole set of indicators of the degree of international authority, the number and ratifications of international treaties, the addressees of justification, the role of common goods, and so on consistently demonstrate an enormous growth after the fall of the Soviet empire ( $A$ Theory, chs. 1 and 5). This parallel and significant leap of indicators points to a system change that took place in the 1990s. International institutions at that time became more intrusive in that they practiced the enforcement of peace, strengthened mechanisms for the protection of human rights and pressed for neo-liberal economic recipes as well as the opening of borders. Most of those new governance institutions pointed to a strong liberal order in that they contained a liberal purpose, whereas the immediate post-World War II period and some global governance mechanisms before were much less intrusive and only weakly liberal in the sense of being 'rule-based'. ${ }^{13}$

\footnotetext{
${ }^{9}$ Zürn 2018b.

${ }^{10}$ Barnett 2020.

${ }^{11}$ Morse and Keohane 2014.

${ }^{12}$ Barnett 2020; Keohane 2020.

${ }^{13}$ E.g. Ikenberry 2001.
} 
The combination of change in the underlying normative principles of global governance, the authority of global governance institutions and their increasing interactions brings me to speak of the 1990s as the period during which the current global governance system became established.

This view about the timing of the global governance system does in no way question some of the important observations put forward by my critics. First and without a doubt, I confess that the book does not give an account of the historical roots of current global governance norms as, for instance, Christian Reus-Smit has done regarding the role of individual rights or Vincent Pouliot regarding some diplomatic practices. ${ }^{14}$ Second, international and transnational authorities certainly existed before the 1990s, including the United Nations Security Council (UNSC) and the Bretton Woods institutions. Especially, the UNSC, however, exercised authority more vividly after 1990 than before. I also do not deny that even earlier periods of the international system contained some sectoral authoritative institutions like the International Postal Union or the International Telecommunication Union. The concept of authority can thus be used to analyze earlier periods of world politics.

Given these observations, it is certainly correct to state that many consequential international institutions and practices were in place before the majority of the current states entered the international arena. ${ }^{15}$ At the same time, it is also true that many international and transnational authorities came into existence only after decolonization unfolded. Even those international authorities that were there earlier - such as the post-World War II institutions - affect not only the new states but also those states that founded them in the first place. In many cases the birthday of international and transnational authorities is more recent than the birthday of the states affected by them. Therefore, an account of international authority based on socialization (inscribed authority) does not suffice. In any case, it seems to be a valid question to ask in future studies to what extent authority plays out differently in states that were born into existing authority structures as opposed to those that were active in developing them. This distinction may help to shed additional light on the relationship between inscribed and reflexive authority.

I am also ready to concede that $A$ Theory focuses empirically too much on intergovernmental institutions, in spite of being conceptually open to transnational and hybrid forms of governance. And this focus to some extent is indeed a function of the focus on the 1990s and the early 2000s when global governance was primarily associated with IOs. Many contributors to this symposium suggest taking into account a changing 'mode of global governance'. In such a new mode of a global political system, the role of intergovernmental organizations may have diminished and there may have been a rise of transnational or hybrid institutions often equipped with epistemic authority. As Kelley and Simmons hypothesize, '[w]hen IOs face challenges to their authority, they have incentives to develop tools that garner less resistance. ${ }^{16}$ Scholte suggests that 'the main growth areas of recent global governance lie in alternative organizational forms such as transgovernmental

\footnotetext{
${ }^{14}$ Reus-Smit 2013; Pouliot 2016.

${ }^{15}$ Pouliot 2020.

${ }^{16}$ Kelley and Simmons 2020, 171.
} 
networks, private regulation, and multi-stakeholder arrangements' ${ }^{17}$ Regarding the last two decades, they are certainly right. However, new modes of global governance do not come from anywhere; they often need the failure of intergovernmentalism as background. It is this failure that is at the core of $A$ Theory, which can be extended to an analysis of changes in modes of global governance. It seems that to the extent that contestations of global governance grow, epistemic authority becomes more relevant than political authority. This implies a faster rise of transnational authority than intergovernmental authority. Whether this process reduces contestation over the rules and norms that inform global governance remains to be seen.

\section{Reflexive authority and coercion}

The concept of reflexive authority is key for $A$ Theory. Reflexive authority describes a relationship between often very small IOs with few resources exercising authority over states with enormous amounts of economic and military resources. This leads to the question of why powerful states should obey the directives of an IO? ${ }^{18}$ The notion of reflexive authority is an answer to that question. Reflexive authorities depend even more on recognition than traditional authorities such as masters, churches, and state institutions because they can hardly build on socialization or employ superior resources. Reflexive authorities are anchored in issue-specific variants of a common knowledge order that is roughly in line with what the Stanford School sees at the core of world society. ${ }^{19}$ The source of recognition of reflexive authorities thus is different than in rationalist accounts (where contracts are the major source) or in constructivist accounts (where socialization and internalization is central). ${ }^{20}$ Reflexive authority therefore emphasizes requests rather than demands. From this perspective, global governance institutions try 'to be effective, without being overly directive'. ${ }^{21}$ Although my critics accept the concept of reflexive authority, they consider it too focused on consensus instead of coercion, ${ }^{22}$ too preoccupied with institutional features instead of long-standing practices ${ }^{23}$ or deeper structures, ${ }^{24}$ and too ignorant of some decisive new 'materialist characters' ${ }^{25}$

Both rule and authority are anchored in a relationship of recognition of superand subordination. ${ }^{26}$ In the absence of any recognition of the superordinate by the subordinate - that is, when subordination is based only on coercion - we would have to speak of tyranny. Tyranny however is rare, especially when it comes to IOs. Therefore, I do not accept the juxtaposition of authority that is consensusbased and legitimate by definition and other forms of rule that are force-based

\footnotetext{
${ }^{17}$ Scholte 2020, 181.

${ }^{18}$ Keohane 2020.

${ }^{19}$ Meyer et al. 1997.

${ }^{20}$ Hurd 2007; Lake 2010.

${ }^{21}$ Kelley and Simmons 2020, 172.

${ }^{22}$ Deitelhoff and Daase 2020.

${ }^{23}$ Pouliot 2020.

${ }^{24}$ Scholte 2020.

${ }^{25}$ Leander 2020.

${ }^{26}$ See Furedi 2013.
} 
and illegitimate. ${ }^{27}$ In my view, both authority and rule can contain different blends of recognition and coercion, but both are anchored in a relationship of recognition. Each authority relationship and each system of rule contains Weber's 'minimum willingness to obey ${ }^{28}$ which varies significantly, of course. Thus, each authority relationship is to some extent built on a social paradox that can be characterized as 'affirmed dependency ${ }^{\text {'2 }}$ or 'complicity of the dominated'30 and already points to the seeds for contestation and resistance. Contestation and resistance are as much part and parcel of authority as they are of rule. Thereby, the relative levels of recognition and resistance may be influenced by, but are independent of, the material backing of authority and rule. Whereas even strongly 'closed ruling orders $^{31}$ sometimes face little resistance, reflexive authorities may face a lot of contestation, sometimes even in the form of dissidence.

Instead of the degree of recognition, I distinguish between rule and authority on another count. I define rule as a generalized or systemic relationship, whereas authority refers to a relationship limited to a certain function. The fitness instructor exercises authority over a CEO of a big company regarding the right workout, whereas the Hegelian master exercises rule over the slave in much more general terms. Within such a system of rule, many specific authorities are a subset of the overall set. Yet, specific authorities can also exist outside a system of rule. Ceteris paribus, systems of rule contain more opportunities for power exertion and coercion than issue-specific authority relationships. The same is true for the current global governance system that is best described as a system of rule of loosely coupled spheres of authority. Indeed, the legitimation problems that drive current contestations are rarely issue-area specific but systemic. The technocratic bias in the legitimation narratives and the lack of impartiality in the exercise of international authority are in my analysis due to features of the global governance system that derive from patterns of interaction between reflexive authorities. Deitelhoff and Daase are therefore right in pointing out that contestations do not only speak to specific authorities but are nurtured by features of the system of loosely coupled spheres of reflexive authorities as a whole. ${ }^{32}$

Against this background, Pouliot applauds the notion of loosely coupled reflexive authorities, but wonders whether states defer to politically assigned epistemic authorities 'because the latter "know better." 33 He points to stubbornly held moral orders, the presence of permanent contestations, and the absence of a common epistemological framework as reasons to doubt the power of reflexive authorities. In the author's view, hierarchies - often based more on coercion than on recognition - are equally important. In contrast, $A$ Theory argues that there are underlying knowledge orders that are hardly challenged, partially because they refer to stubbornly held normative beliefs, partially because they are often based on an instrumentalist mode of thinking. The reflexivity of reflexive authorities,

\footnotetext{
${ }^{27}$ Deitelhoff and Daase 2020.

${ }^{28}$ Deitelhoff and Daase 2020.

${ }^{29}$ Horkheimer 1987 [1936].

${ }^{30}$ Bourdieu 1990.

${ }^{31}$ Deitelhoff and Daase 2020.

${ }^{32}$ Deitelhoff and Daase 2020.

${ }^{33}$ Pouliot 2020, 145.
} 
therefore, refers to the permanent questioning of the requests, not to the questioning of the underlying knowledge orders. In any case, international and transnational authorities are permanently under observation and regularly questioned.

Reflexive authorities and the system of loosely coupled systems can nevertheless force actors in world politics and world society to do things that they do not want to do in different ways. First, even reflexive authorities can exert coercive power. Authority in global governance can namely take two forms: epistemic or political authority. Some of the global political authorities indeed go beyond requests and have a recognized right to sanction (Security Council), to conditionality (International Monetary Fund), or to demand compensation payments (World Trade Organizations). However, in the absence of coercive means on the side of international authorities, the ability to use the right of enforcement depends on the resources of the most powerful states. Reflexive authorities are, therefore, to a significant extent tools of more powerful states to exercise control over less powerful ones. In such institutions, sovereign inequality is institutionalized and leads to a stratification between states.

Second, reflexive authorities, especially epistemic authorities, may exert power over actors who do not recognize the authority by exercising authority over actors that can put pressure on them. In such a triangular structure, rating agencies, for instance, brought Greece, and more recently Italy, to accept austerity policies. This is the general mechanism through which governance (by numbers) works. As highlighted by Kelley and Simmons, private rating agencies 'activate transnational pressures and influence how third parties such as foreign investors, donors or other states respond to - or are anticipated to respond to - the ratings' ${ }^{34}$

The interplay between reflexive authorities in a system of loosely coupled spheres of authority is a third source of coercive power via excluding actors from decisions that affected the latter though they have no say in any of the decision-making. ${ }^{35}$ Last but not least, recognition in reflexive authority is based on knowledge structures. Even when reflexive authorities remain 'soft', ${ }^{36}$ they may be evil and in a certain way 'coercive'. This Foucauldian insight about knowledge orders should not be neglected - especially not by critical perspectives. ${ }^{37}$ It points to the importance of the second and the third face of power especially, as Lukes would put it, because epistemic authorities are indeed weaker regarding the first face. ${ }^{38}$

Moreover, the underlying knowledge order of reflexive authorities does not only contain power potentials, it also relates to some of the deeper social structures such as capitalism and the notion of sovereignty. As Scholte states, 'deeper structures have powerful impacts on institutional arrangements, and vice versa' ${ }^{39}$ Although I strongly agree and consider 'deeper structures' an important foundation on which a global political system is built, I do not theorize them. A Theory is a theory of the current global governance system that takes capitalism and competing territorial states as 'problems to be regulated' and as constitutive 'structures that

\footnotetext{
${ }^{34}$ Kelley and Simmons 2020.

${ }^{35}$ Eriksen 2018.

${ }^{36}$ Deitelhoff and Daase 2020.

${ }^{37}$ Foucault 1998.

${ }^{38}$ Lukes 1974.

${ }^{39}$ Scholte 2020, 184.
} 
influence actors' not least by constraining cognitions and practices. Similarly, it takes the change of technology as given, whereas accepting the claim that markets, minions, and mimes are not central to A Theory. ${ }^{40}$

In sum, reflexive authorities in global governance - even when based on recognition are not only an expression of the 'pleasant sides of international institutions ${ }^{\text {'41 }}$ but also reflect the dark sides of social structures. This is one of the reasons why they produce contestation and why I reject the Parsonian understanding of authority as legitimate rule. Yet, my critics are right in arguing that other forms of super- and subordination in past international systems (e.g. imperialism) and in present world society (e.g. global production processes) are not captured by reflexive authority relationships between global governance institutions and states as well as societies. A Theory is a theory about the global political system; not about domination in world society in general. It would be indeed a most interesting project to relate the current global governance system to the deeper structures of world society and their material characters. My critics are certainly right in arguing that this would enrich $A$ Theory. Moreover, they point to an interesting path of inquiry in the study of authority relationships: Is the blend between recognition and different types of coercion systematically related to levels and types of contestation?

\section{Legitimation and dissenters of global governance}

Legitimacy is important in global governance. In general, any system of rule and any authority that is considered legitimate is ceteris paribus much more efficient and effective than one without legitimacy. ${ }^{42}$ Therefore, authorities produce legitimation narratives. My critics point to two critical issues in this regard.

The first of these questions refers to the legitimation practices of authority holders in global governance and their defenders. Barnett specifically inquires whether a focus on procedures is sufficient to grasp different sources of legitimacy. ${ }^{43}$ A Theory indeed distinguishes between the quality of decision making and the quality of decisions as two principal sources of legitimacy. According to this well-established distinction, ${ }^{44}$ "both the achievement of common goods (e.g., social welfare) and the way the decision has been made (e.g., democratic participation) can serve as sources of legitimacy' ${ }^{45}$ Thus, in practice, political and epistemic authorities combine different sources to legitimate themselves. For this very reason, 'legitimation narratives' are essential to understanding the justifications offered by authority holders and their defenders.

More importantly, Keohane asks about the causal relevance of legitimation narratives. ${ }^{46}$ Are the legitimation narratives and their ingredients really the major issue of current contestations in world politics? In response, I first of all take side with Barnett in stating that the technocratic legitimation narrative is the most important

\footnotetext{
${ }^{40}$ Leander 2020.

${ }^{41}$ Deitelhoff and Daase 2020, 145.

${ }^{42}$ Lindblom 1977.

${ }^{43}$ Barnett 2020.

${ }^{44}$ Tallberg and Zürn 2019.

${ }^{45}$ Zürn 2018a, 69-70.

${ }^{46}$ Keohane 2020.
} 
one for global governance institutions. ${ }^{47}$ This, however, is a most bloodless legitimation narrative that is easily overburdened by the real intrusiveness of international authorities. It is the lack of legitimation narratives with stronger senses of belonging and with more emotive quality that constitutes one part of the legitimacy crisis of global governance.

The other major reason for the legitimacy crisis of global governance is the growing perception of partiality in the exercise of authority. In the eyes of many dissenters, the permanent employment of double standards undermines the credibility of existing authorities. To be sure, authority does not have to be equally distributed, and the rules may reflect different interests to varying degrees. However, the moment authorities exercise the rules unevenly, authority is considered hypocritical and legitimacy evaporates.

The decisive point in response to the question of whether legitimacy issues are under question now is that all the five types of dissenters of global governance justify their demands for change with legitimacy concerns: (i) some of the rising powers, (ii) elected authoritarian populists, (iii) authoritarian populist parties within consolidated democracies, (iv) fundamentalist religious forces, and (v) leftist transnational movements complaining about neo-liberal excesses. Rising powers, Islamic movements, and some autocratic leaders complain about the double standards or lack of impartiality of international institutions. They want to increase their power in these international institutions or reject them completely as instruments of Western dominance. Many transnational movements and authoritarian populist parties in Western democracies complain about technocratic and uncontrolled bureaucrats. The transnational movements therefore often ask for the democratization of international institutions, whereas the populist parties want to take back control again. All the current dissenters, as different as they are, thus speak to the legitimation problems of the current global governance system. Although some of these justifications may be instrumental, the commonality of justificatory practices makes it unlikely that legitimacy concerns are causally irrelevant.

My critics also raise the question of the relevant holders of legitimacy beliefs. Barnett, for instance, asks: Who are the audiences that determine the legitimacy of international institutions and on which basis ${ }^{48}$ Similarly, Scholte, as well as Keohane, detect an analytical bias in favor of rising powers and some non-state actors in the Western world as the decisive audiences. ${ }^{49}$ They are right in pointing out that there may be many other groups and individuals than rising powers and non-state actors who feel that international institutions are illegitimate, and even more than the five types of dissenters identified above. In A Theory, my focus is on those contestations that are the most important for the current global governance system. Although a lack of legitimacy produces an opportunity structure for politicization, contested multilateralism, nationalist protests, or even dissidence, it also requires social mobilization before it becomes relevant for global governance institutions. The latter step depends on sufficient resources for mobilization, but not necessarily on the quality of reasons for contestation. In that sense, a complete

\footnotetext{
${ }^{47}$ Barnett 2020; see also Barnett and Finnemore 2004.

${ }^{48}$ Barnett 2020.

${ }^{49}$ Keohane 2020; Scholte 2020.
} 
analysis of the beliefs of people and groups affected by global governance including their capacity to mobilize is indeed missing. A typology of different contestations of the global political system is needed.

\section{On epistemology and all that}

By way of conclusion, I would like to address questions about ontology, epistemology, normativity, and positionality raised by critics. First, on ontology: although I find the account of a new world that requires a complete divorce from existing IR ontology as sketched by Leander interesting, $A$ Theory follows a traditional account. ${ }^{50}$ Accordingly, governance actors such as state governments, national parties, transnational movements, international and transnational authorities, and also private companies aim at regulating social processes (of which they are part of) and new technologies. Although it may be worthwhile to develop a theory of cybersecurity governance based on a radically new ontology that focuses on 'markets, minions and mimetic bodies' ${ }^{51} A$ Theory certainly is the wrong place to search for it.

Second, in response to Pouliot on epistemology: by developing an endogenous explanation of the crisis of global governance, I am pressed to identify causal pathways through which the rise of international and transnational authority has produced a crisis. ${ }^{52}$ The empirical validity of such mechanisms can be probed both by looking at a historical account of the sequence of events (since it is by definition a single case) and by a permanent double-checking whether the assumed micromechanisms on which the pathways are built are generalizable. In this way, I believe that the strongest explanations of contemporary global governance combine withincase interpretations with across-case comparisons. ${ }^{53}$

Third, on normativity: like Scholte, I do believe that normative thinking is of utmost importance in IR. ${ }^{54}$ Normative thinking helps us ask the right questions and identify the problems: for example, why is something in crisis that is normatively defensible, such as global governance? It also helps to refine some of our analytical concepts that do the explanatory work (e.g. legitimacy or impartiality). And normative theory is necessary to evaluate political projects, visions, and ideologies, including whether a global order with cosmopolitan intent is possible and desirable at all? In this way, there is a close interaction between normative and empirical reasoning in A Theory. On the level of single statements, however, we can and need to distinguish between is and should statements. Since empirical and normative statements interact on the level of theory, blaming a theory for its built-in normativity, as does Barnett, looks to me like an expression of pre-Popperian positivist thinking. ${ }^{55} A$ Theory is certainly influenced by normative thinking, which considers human rights, the rule of law, and democracy as the cornerstones of a normatively defensible political order.

\footnotetext{
${ }^{50}$ Leander 2020.

${ }^{51}$ Leander 2020.

${ }^{52}$ Pouliot 2020.

${ }^{53}$ See Goertz 2017.

${ }^{54}$ Scholte 2020.

${ }^{55}$ Barnett 2020.
} 
Fourth, on positionality: Keohane and Scholte are therefore undoubtedly right in pointing to the positionality of all of our work. ${ }^{56} A$ Theory is a book by a European, and the perspective it provides can be called a European perspective, as much as many other IR books are books by Americans providing American perspectives. The positionality of $A$ Theory shows not least by the choice of contestations that are at the core of the book. A book on contestations of global governance from a post-colonial perspective certainly would put other dissenters at the center of the analysis. There is no analysis and no thinking that is free of positionality. As the authoritarian populists have taught us, even the cosmopolitan 'Nowheres ${ }^{57}$ that run the global governance institutions on technocratic grounds can be blamed for being partial.

Acknowledgement. I want to thank the editors of this symposium, Orfeo Fioretos and Jonas Tallberg, two anonymous reviewers, as well as Jelena Cupać and Christian Kreuder-Sonnen for very helpful comments to an earlier version of this contribution.

\section{References}

Barnett, Michael. 2020. “Change in or of Global Governance?” International Theory 13 (1): 131-43.

Barnett, Michael, and Martha Finnemore. 2004. Rules for the World. International Organizations in Global Politics. Ithaca, NY: Cornell University Press.

Bourdieu, Pierre. 1990. The Logic of Practice. Stanford: Stanford University Press.

De Wilde, Pieter, Ruud Koopmans, Oliver Strijbis, Céline Teney, Bernhard Wessels, and Michael Zürn eds. 2019. Struggle over Borders: The Political Sociology of Cosmopolitanism and Communitarianism. Cambridge, New York: Cambridge University Press.

Deitelhoff, Nicole, and Christopher Daase. 2020. "Rule and Resistance in Global Governance." International Theory 13 (1): 122-30.

Eriksen, Erik Oddvar. 2018. "Political Differentiation and the Problem of Dominance: Segmentation and Hegemony.” European Journal of Political Research 57 (4): 989-1008.

Fioretos, Orfeo, and Tallberg, Jonas. 2020. "Politics and Theory of Global Governance". International Theory 13 (1): 99-111.

Foucault, Michel. 1998. The History of Sexuality: The Will to Knowledge. London: Penguin.

Furedi, Frank. 2013. Authority. A Sociological History. Cambridge, New York: Cambridge University Press.

Goertz, Gary. 2017. Multimethod Research, Causal Mechanisms, and Case Studies: An Integrated Approach. Princeton: Princeton University Press.

Goodhart, David. 2017. The Road to Somewhere: The Populist Revolt and the Future of Politics. London: C. Hurst \& Co.

Horkheimer, Max. 1987 [1936]. “Allgemeiner Teil,” in M. Horkheimer (ed.) Studien über Autorität und Familie (2nd edn, Lüneburg: Dietrich zu Klampen Verlag), 3-76.

Hurd, Ian. 2007. After Anarchy. Legitimacy and Power in the United Nations Security Council. Princeton: Princeton University Press.

Ikenberry, G. John. 2001. After Victory. Institutions, Strategic Restraint, and the Rebuilding of Order After Major Wars. Princeton: Princeton University Press.

Inglehart, Ronald, and Pippa Norris. 2016. "Trump, Brexit, and the Rise of Populism: Economic Have-Nots and Cultural Backlash.” HKS Working Paper No. RWP16-026. Posted: 6 August 2016.

Kelley, Judith, and Beth A. Simmons. 2020. "Governance by Other Means: Rankings as Regulatory Systems.” International Theory 13 (1): 169-78.

Keohane, Robert O. 2020. “The Global Politics Paradigm: Guide to the Future or Only the Recent Past?" International Theory 13 (1): 112-121.

\footnotetext{
${ }^{56}$ Keohane 2020; Scholte 2020.

${ }^{57}$ Goodhart 2017.
} 
Lake, David. 2010. "Rightful Rules: Authority, Order, and the Foundations of Global Governance." International Studies Quarterly 54 (3): 587-613.

Leander, Anna. 2020. "Locating (New) Materialist Characters and Processes in Global Governance." International Theory 13 (1): 157-68.

Lindblom, Charles E. 1977. Politics and Markets: The World's Political-Economic Systems. New York, NY: Basic Books.

Lukes, Stephen. 1974. Power: A Radical View. London: Macmillan Press.

Meyer, John W., John Boli, George W. Thomas, and Francisco O. Ramirez. 1997. "World Society and the Nation State." American Journal of Sociology 103 (1): 144-81.

Morse, Julia C., and Keohane, Robert O. 2014. "Contested Multilateralism." Review of International Organizations 9 (4): 385-412.

Pouliot, Vincent. 2016. International Pecking Orders. The Politics and Practice of Multilateral Diplomacy. New York: Cambridge University Press.

Pouliot, Vincent. 2020. "Global Governance in the Age of Epistemic Authority." International Theory 13 (1): 144-56.

Reus-Smit, Christian. 2013. Individual Rights and the Making of the International System. Cambridge, New York: Cambridge University Press.

Ruggie, John G. 1983. "International Regimes, Transactions, and Change: Embedded Liberalism in the Postwar Economic Order." In International Regimes, edited by Stephen D. Krasner, 195-231. Ithaca: Cornell University Press.

Scholte, Jan Aart. 2020. "Beyond Institutionalism: Toward a Transformed Global Governance Theory." International Theory 13 (1): 179-91.

Tallberg, Jonas, and Michael Zürn. 2019. "The Legitimacy and Legitimation of International Organizations. Introduction and Framework." Review of International Organizations 14 (4): 581-606.

Zürn, Michael. 2018a. A Theory of Global Governance: Authority, Legitimacy, and Contestation. Oxford: Oxford University Press.

Zürn, Michael. 2018b. "How the Taming of the Class Conflict Produced Authoritarian Populism." Items: Insights from the Social Sciences." https://items.ssrc.org/how-the-taming-of-the-class-conflict-producedauthoritarian-populism/.

Cite this article: Zürn, M. 2021. "On the role of contestations, the power of reflexive authority, and legitimation problems in the global political system.” International Theory 13, 192-204, doi:10.1017/ S1752971920000391 